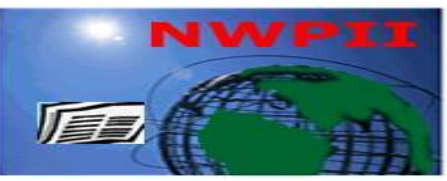

American Journal of Biomedical Sciences

ISSN: 1937-9080

nwpii.com/ajbms

\title{
Effect of Garlic Extract (Allium Sativum) on Lipid Profile of Wister Rats
}

\author{
Obisike, Uchechukwu Achor ; Elekima, Ibioku; Aleru, Constancy Prisca; Christian, Serekara
}

Medical Laboratory Department, Rivers State University of Science and Technology, Nkpolu-Oroworukwo, Port Harcourt, Rivers State, Nigeria.

"Corresponding Author

Obisike, Uchechukwu Achor

Medical Laboratory Department

Rivers State University of Science and Technology

Nkpolu-Oroworukwo, Port Harcourt

Nigeria

Email: obisike.uchechukwu@ust.edu.ng

Received: 12 February 2016; | Revised: 02 May 2016; | Accepted: 17 May 2016

\begin{abstract}
Lipid profile in Wister rats was investigated after administration of different concentration of aqueous extract of Allium sativum. The animals were divided into five (5) groups of five rats in each group, and were given different concentrations of the extract for three weeks. Thereafter, plasma lipid profiles were assayed. The result of comparing the mean total cholesterol (T. CHOL), triglyceride (TG), Low density lipoprotein (LDL) and control levels with those of the test groups A, B, C and D showed great decrease except in group $\mathrm{D}$ where there was an increase in mean LDL. The decrease in mean T.CHOL in group $\mathrm{A}$ and $\mathrm{C}$ were significant while decrease in T.CHOL in group B and D were not significant when compared with T.CHOL of Control samples at $\mathrm{p}<0.05$. The decrease in TG was significant in all test groups when compared with Control TG samples at $\mathrm{p}<0.05$, while the decrease in LDL in group D was not significant when compared with the LDL control samples at $p<0.05$. The mean HDL of the test group showed a great increase when compared with the mean Control and the increase observed was significant when compared with the Control HDL at $\mathrm{p}<0.05$. The findings reveal that garlic bulb extract causes a significant reduction in some lipid profile parameters $(p<0.05)$ especially TG and an increase in HDL. These findings therefore suggest that the administration of Allium sativum extract could prevent plasma lipid related disease especially those associated with cardiovascular disease and atherosclerosis.
\end{abstract}

Keywords: Garlic extract, lipid profile, Wister Rat.

\section{Introduction}

The presence of phytochemical compounds found in plants is now recognized as having important roles in disease prevention, possibly through their effects on oxidative damages [1]. Garlic contains phytochemicals, which are responsible for the sharp flavor of garlic when the plant's cells are damaged either by chopping, chewing, or crushing. During this process the 
enzymes stored in cell vacuoles of garlic trigger the breakdown of several sulfur-containing compounds stored in the cell fluids (cytosol) [2]. Allium sativum, commonly known as garlic, is a perennial erect, bulbous herb belonging to the

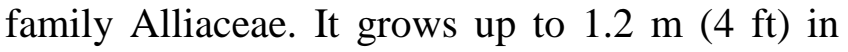
height and is the second most widely cultivated crop in the family after onion [3]. It consists of an underground bulb and an above ground vegetative part, which also consist of a flat as well as slender leaves. Its rooting system is fibrous, while the bulb comprises of small bulblets called cloves [4]. A sativum is widely cultivated for culinary purposes because of its strong smell especially when crushed, and also for its medicinal properties [4].

The most edible part is the bulb, which is referred to as, Camphor of the Poor, Sinking Rose, Nectar of the Gods, Poor Man's Treacle, Rust Treacle, and also garlic. The bulb is a fundamental component in most dishes of various regions, including Eastern Asia, South Asia, Southeast Asia, the Middle East, Africa, Southern Europe, and parts of South and Central America [5]. With the exception of the single clove (bulb) types, garlic bulbs are formally divided into numerous fleshy sections called cloves. Each clove is covered by parchment-like skin much like the skin of an onion; the parchment skin is removed before using in raw or cooked form [6]. Garlic cloves are used for consumption (raw or cooked) or for medicinal purposes. They have a characteristic pungent, spicy flavor that mellows and sweetens considerably with cooking. The leaves and flowers (bulbils) on the head (spathe) are also edible, they are milder in flavor than the bulbs, and are most often consumed while immature and still tender. In Korea, heads of garlic are fermented at high temperature; the resulting product is called black garlic, is sweet and syrupy, and is now being sold in the United States, United Kingdom and Australia [6]. One of which is allicin, which is the compound most responsible for the hot sensation of raw garlic and it has been found that it lowers serum cholesterol level [2]. While its decomposition products diallyl disulfide and diallyl trisulfide are known for their antihyperlipidemic properties. Other allicin-derived compounds, such as .vinyldithiins and ajoene show beneficial in vitro biological activity [2], [7] Phytoalexin (allixin) found in garlic, is a nonsulfur compound with a y-pyrone skeleton structure and has antioxidant, antimicrobial, and antitumor promoting effects, inhibition of aflatoxin B2 DNA, binding, and neurotrophic effects [8]. An environmentally benign garlic-derived polysulfide product is approved for use in the European Union (under Annex 1 of 91/414), and in UK most garlic product are manufactured to be used as an insecticide, and for use to control cabbage root fly and red mite in poultry [9]. Garlic has been found to enhance thiamin absorption, and therefore reduces the likelihood of developing thiamin deficiency (beriberi) [10]. It was also found to be an effective way to prevent scurvy, because of its high vitamin $C$ content [10]. In Nigeria, garlic grows more in the Northern States; the bulb is used as spice in stew, salad, seasoning of meat and vegetables. It is also used for preserving meat and spice products and as a flavouring ingredient in baked foods such as bread, biscuits and meat pie. The extract is used as an antidote against poisons, as well as antibacterial [4].

\section{Material and Method}

\subsection{Experimental Animals}

Twenty five (25) adult male albino Wister rats that weighed $190 \mathrm{~g}$ to $400 \mathrm{~g}$ were bought from the animal house of Anatomy Department, College of Health sciences, University of Port Harcourt (UNIPORT), Rivers State. The animals were held in well ventilated cages where they had access to food (Finisher) and water. Their cages were cleaned daily, and their water and feed were changed daily. They were housed under standard condition of room temperature and in twelve (12) hour light and twelve (12) hour dark cycle. The animals were kept and cared for under standard guidelines of laboratory animal handling. One week was given to them to acclimatize. After acclimatization they were divided into five groups on the basis of difference in weight.

The groups were designated A, B, C, D and control. Group A, B, C, and D, received 
$100 \mathrm{mg} / \mathrm{ml}, 300 \mathrm{mg} / \mathrm{ml}, 600 \mathrm{mg} / \mathrm{ml}$ and $1000 \mathrm{mg} / \mathrm{ml}$ doses of the A. sativum bulb extract respectively.

\subsection{Preparation of Extract}

A sativum bulb was obtained from mile 3 market Port Harcourt. The gloves (parchment skin) were removed from the bulb, after which the bulbs were weighed. Then a measured weight of thirty grams $(30 \mathrm{~g})$ of the peeled garlic bulbs was grounded using the standard laboratory mortar and pestle. $100 \mathrm{ml}$ of distilled water was added to the grounded garlic, and allowed for 30minutes. After which the solution of garlic was sieved, using $1 \mathrm{~mm}$ sieve to obtain a homogenous extract. The filtrate when measured weighed $10 \mathrm{~g}$. Therefore the garlic extract solution contained $20 \mathrm{~g}$ of garlic.

\subsection{Preparation of Test Drug from the Extract}

$30 \mathrm{~g}$ of grounded garlic was reconstituted into $100 \mathrm{ml}$ of distilled water, the filtrate weighed $10 \mathrm{~g}$. The concentration of garlic in the solution will be equal to $20 \mathrm{~g}(30 \mathrm{~g}-10 \mathrm{~g})$ of garlic in $100 \mathrm{ml}$ of distilled water. Therefore,

$1 \mathrm{ml}$ of extract $=200 \mathrm{mg} / \mathrm{ml}=0.2 \mathrm{~g}$ of garlic.

$0.5 \mathrm{~m} 1$ of extract $=100 \mathrm{mg} / \mathrm{ml}=0.1 \mathrm{~g}$ of garlic.

$1.5 \mathrm{~m} 1$ of extract $=300 \mathrm{mg} / \mathrm{ml}=0.3 \mathrm{~g}$ of garlic.

$3.5 \mathrm{ml}$ of extract $=600 \mathrm{mg} / \mathrm{ml}=0.7 \mathrm{~g}$ of garlic.

$5.0 \mathrm{ml}$ of extract $=1000 \mathrm{mg} / \mathrm{ml}=1.0 \mathrm{~g}$ of garlic.
Groups A, B, C, and D received $100 \mathrm{mg} / \mathrm{ml}$, $300 \mathrm{mg} / \mathrm{ml}$, $\quad 600 \mathrm{mg} / \mathrm{ml}$ and $100 \mathrm{mg} / \mathrm{ml}$ respectively, control group were not fed with the extract.

\subsection{Administration}

Administration of the extract was done by means of oral compulsion. This was done using oral canula which was inserted into the mouth of the animal and administered slowly to ensure that the volume measured was completely delivered, the extract was administered daily.

\subsection{Collection of Blood}

Group A, B, C and D were fed for three weeks with the extract, while the control group was not fed with the extract. 12 hours after the last administration, the rats in all the groups were sacrificed. Using a sterile syringe and needle, blood was collected from the jugular vein. The blood collected was transferred into lithium heparin bottle. They were spun and separated. Plasma lipid profile was done using an Automatic Chemistry Analyser.

\section{Results}

The results of the analysis carried out were subjected to a student t-test using Microsoft excel at $95 \%$ confidence level. The results were expressed as Mean \pm Standard deviation.

Table 4.1 Results of Mean and Standard Deviations of analyzed lipid profile of Control and Group A to D

\begin{tabular}{|c|c|c|c|c|}
\hline Groups & T.Chol & T.G & HDL & LDL \\
\hline Control & $1.4 \pm 0.14$ & $1.19 \pm 0.28$ & $0.30 \pm 0.14$ & $0.53 \pm 0.15$ \\
\hline Group A(100mg/ml) & $1.02 \pm 0.10$ & $0.67 \pm 0.17$ & $0.56 \pm 0.18$ & $0.15 \pm 0.35$ \\
\hline Group B(300mg/ml) & $1.01 \pm 0.35$ & $0.59 \pm 0.20$ & $0.66 \pm 0.19$ & $0.09 \pm 0.46$ \\
\hline Group C(600mg/ml) & $0.84 \pm 0.11$ & $0.61 \pm 0.31$ & $0.56 \pm 0.16$ & $0.01 \pm 0.09$ \\
\hline Group D(1000mg/ml) & $1.32 \pm 0.37$ & $0.58 \pm 0.13$ & $0.49 \pm 0.09$ & $0.56 \pm 0.38$ \\
\hline
\end{tabular}


Table 4.2 T test of control and group A

\begin{tabular}{|c|c|c|c|c|}
\hline & T.Chol & TG & HDL & LDL \\
\hline Control & $1.37 \pm 0.31$ & $1.19 \pm 0.28$ & $0.30 \pm 0.14$ & $0.53 \pm 0.15$ \\
\hline Group A & $1.02 \pm 0.10$ & $0.67 \pm 0.17$ & $0.56 \pm 0.18$ & $0.15 \pm 0.35$ \\
\hline T value & 2.4070 & 3.54 & 2.5495 & 0.0562 \\
\hline P value & 0.04070 & 0.0075 & 0.342 & 2.2314 \\
\hline Decision & $\mathbf{S}$ & $\mathbf{S}$ & $\mathbf{S}$ & $\mathbf{N S}$ \\
\hline
\end{tabular}

Table 4.3 T test of control and group B

\begin{tabular}{|c|c|c|c|c|}
\hline & T.Chol & TG & HDL & LDL \\
\hline Control & $1.37 \pm 0.31$ & $1.19 \pm 0.28$ & $0.30 \pm 0.14$ & $0.53 \pm 0.15$ \\
\hline Group B & $1.01 \pm 0.35$ & $0.59 \pm 0.20$ & $0.66 \pm 0.19$ & $0.09 \pm 0.46$ \\
\hline T value & 1.7217 & 3.8991 & 3.4108 & 0.0764 \\
\hline P value & 0.1234 & 0.0046 & 0.0092 & 2.0335 \\
\hline Decision & NS & $\mathbf{S}$ & $\mathbf{S}$ & $\mathbf{S}$ \\
\hline
\end{tabular}

Table 4.4 T test of control and control group C

\begin{tabular}{|c|c|c|c|c|}
\hline & T.Chol & TG & HDL & LDL \\
\hline Control & $1.37 \pm 0.31$ & $1.19 \pm 0.28$ & $0.30 \pm 0.14$ & $0.53 \pm 0.15$ \\
\hline Group C & $0.84 \pm 0.11$ & $0.61 \pm 0.28$ & $0.49 \pm 0.10$ & $0.56 \pm 0.38$ \\
\hline T value & 3.6029 & 3.1047 & 2.4694 & 0.1642 \\
\hline P value & 0.0070 & 0.0146 & 0.0387 & 0.8736 \\
\hline Decision & $\mathbf{S}$ & $\mathbf{S}$ & $\mathbf{S}$ & NS \\
\hline
\end{tabular}


Table 4.5 T test of control and control group D

\begin{tabular}{|c|c|c|c|c|}
\hline & T.Chol & TG & HDL & LDL \\
\hline Control & $1.37 \pm 0.31$ & $1.19 \pm 0.31$ & $0.30 \pm 0.14$ & $0.53 \pm 0.15$ \\
\hline Group D & $1.32 \pm 0.37$ & $0.58 \pm 0.13$ & $0.49 \pm 0.10$ & $0.56 \pm 0.38$ \\
\hline T value & 0.2316 & 4.4184 & 2.4694 & 0.1642 \\
\hline P value & 0.8226 & 0.0022 & 0.0387 & 08736 \\
\hline Decision & NS & $\mathbf{S}$ & $\mathbf{S}$ & NS \\
\hline
\end{tabular}

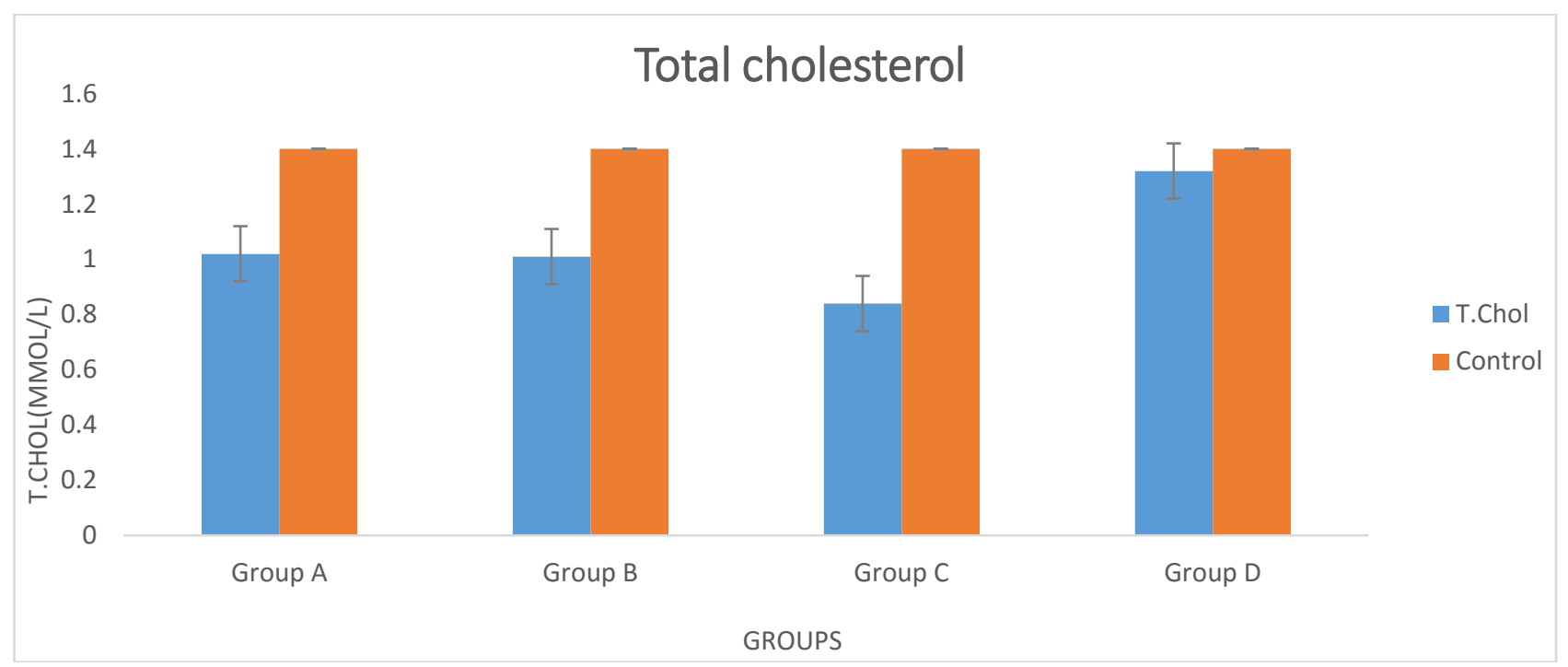

Figure 4.1 Graphical comparison of Mean values of control group and test groups for Total Cholesterol

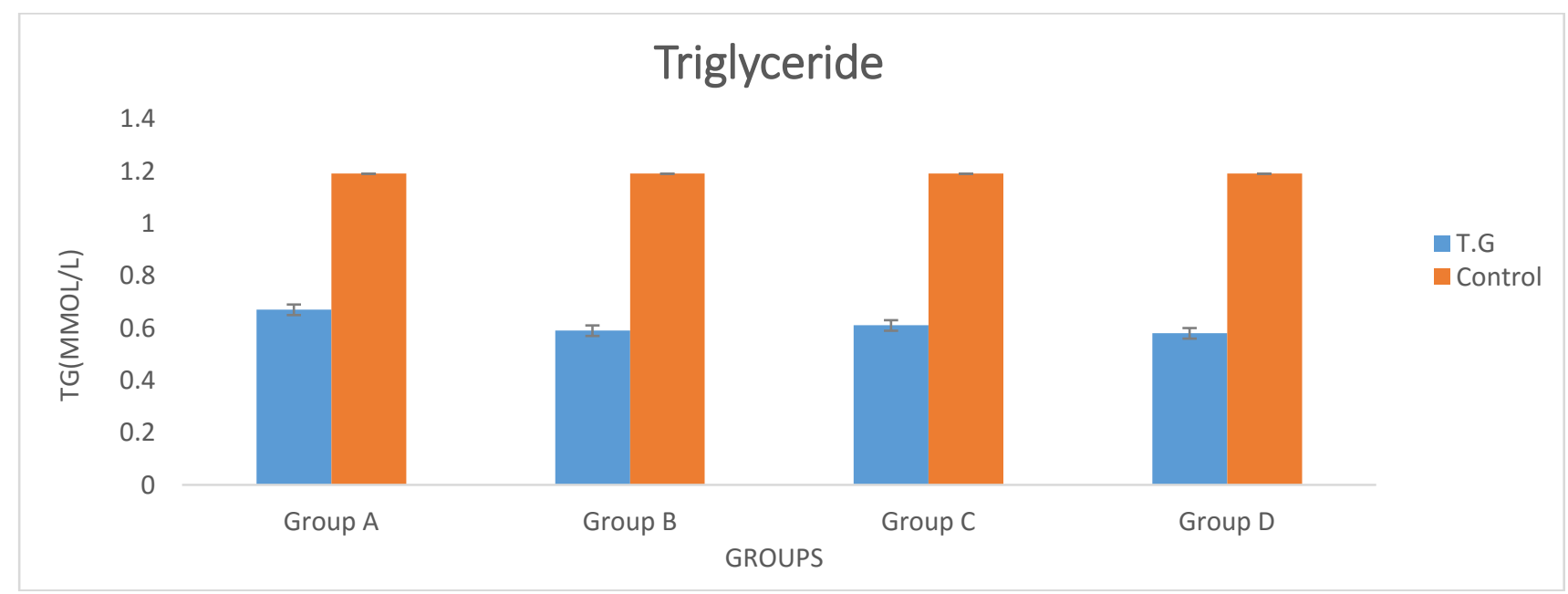

Figure 4.2 Graphical comparison of Mean values of control group and test groups for Triglyceride 


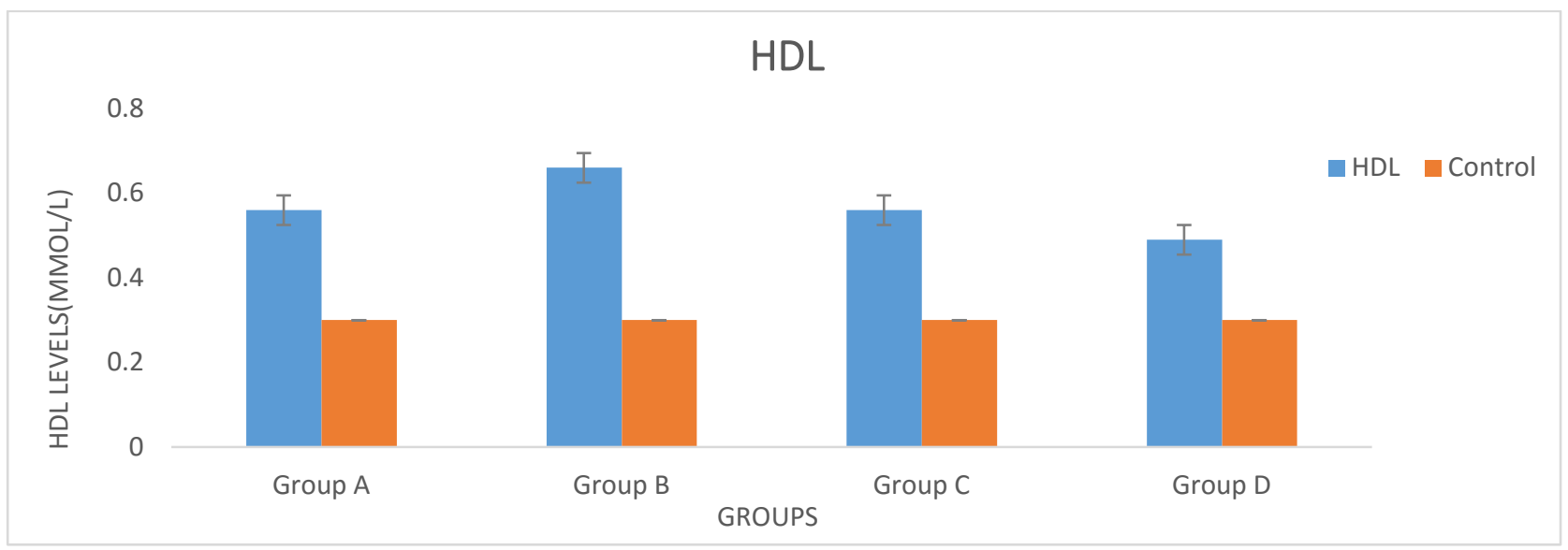

Figure 4.3 Graphical comparison of Mean values of control group and test groups for HDL

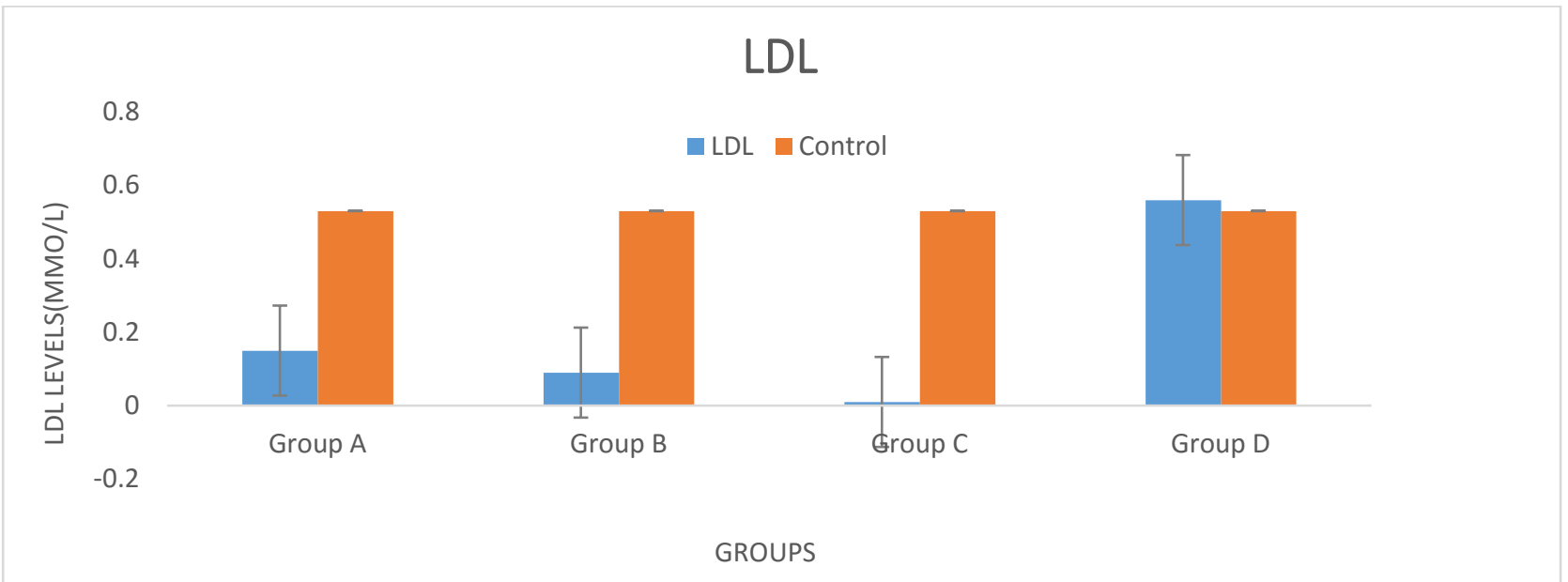

Figure 4.4 Graphical comparison of Mean values of control group and test groups for LDL

\section{Discussion}

The graph in table 4.1 shows how the mean for each lipid parameter varies in each group when compared with the mean of control for the same lipid parameter. For Total Cholesterol, the mean in group $\mathrm{A}, \mathrm{B}$, and $\mathrm{C}$ showed steady decrease when compared with that of control; however at group D there was no much difference in the mean when compared with that of the control. In Triglyceride, there is a great decrease in triglyceride mean value in group $\mathrm{A}, \mathrm{B}, \mathrm{C}$ and $\mathrm{D}$, when compared with the mean triglyceride value of Control. But the decrease observed in the various groups did not follow a specific pattern; the mean triglyceride value in group B was lower than the value in group $\mathrm{A}$, while the value for group $\mathrm{D}$ was much lower than the value of group groups $\mathrm{A}, \mathrm{B}$, and $\mathrm{C}$. The chart for High density Lipoprotein shows clearly that there was an increase in mean value for the various groups when compared with Control, with the control with the highest increase being seen in group B. While in Low density lipoprotein, the mean value for group $\mathrm{A}, \mathrm{B}$, and $\mathrm{C}$ was greatly decreased when compared with that of the Control. The lowest mean Low density lipoprotein value was observed in group $\mathrm{C}$. While the mean Low density lipoprotein value for group D increased more than the control value.

In this study the best result was obtained in group $\mathrm{C}$ where the values of T.CHOL, TG, 
LDL and HDL were significant, proving that garlic extract has implication on lipid values and thus indirectly affects the cardiovascular wellbeing. This is because majority of cardiovascular disease are related to atherosclerosis. An increased risk of coronary heart disease is primarily associated with high serum total cholesterol and their carrier proteins [11]. Lipid management is well established as an effective preventive and management tool for cardiovascular disease [12].

The effect of garlic on lipid values is due to Allicin which is the main constituent of $A$. sativum. It is believed that Allicin is very reactive in lowering serum cholesterol level. [12]. In addition to allicin, Diallyldisulfide (DADS), an active principle component of garlic is known for its antihyperlipidemic properties [13]. Also with respect to the cholesterol lowering property of garlic, it has also been said that some constituents of garlic act as inhibitors for some enzymes such as hydroxyl methyl glutaryl CoA reductase, which participates in cholesterol synthesis [13]. These properties of garlic help in controlling lipid values and thus affects cardiovascular wellbeing and reduces the risks of developing cardiovascular diseases.

\section{Conclusion}

From this study it can be seen that they were significant changes in the lipid profile of the test (various groups) when compared with that of the control, and thus garlic has effect on lipid profile and can also have such effects on cardiovascular diseases that are caused by excessive increase in cholesterol and low density lipoprotein levels. The result of this study also shows that the best effect of garlic extract was achieved in Group $\mathrm{C}$ which received $600 \mathrm{mg} / \mathrm{ml}$ of garlic extract for three week.

\section{Recommendations}

Based on the results of this study, it is recommended that; i. Further large scale studies should be done on human subject to validate the result for wider application on human being, since this work was done on rats and not in humans.

ii. Allium.sativum (garlic) has antilipidemic effect and is good for culinary purpose, but a particular dose should be worked out which will not have ill effects.

iii. Garlic is a good plant, plans should be made by State and Federal Government to localize the cultivation of Garlic in Nigeria, as it has helped to boost the economic growth of countries like India.

\section{References}

1. Prior, R.L. and Cao, G. Antioxidant phytochemicals in fruits and vegetables: Diet and health implications. HortScience, 2000, 35:588-592.

2. Khalid, S.A. Hypocholesteremic and Antioxidant Effects of Garlic (Allium satiuum L.)Extract in Rats Fed High Cholesterol Diet. Pakistan Journal of Nutrition, 2009, 8(2), 161-166. DOI: 10.3923/pjn.2009.161.166

3. Ted, J. M. and Avram, D. Growing Garlic from True Seed. The Heritage Farm Companion, 2012.

4. Hamma, I.L., Ibrahim, U. and Mohammed, A. B. Growth yield and economic performance of garlic (Allium sativum) as influenced by farm yard manure and spacing in Zaria, Nigeria. Journal of Agricultural Economics and Development, 2013, 2(1), 1-5

5. Block, E. Garlic and other Alliums: The lore and the science. Cambridge, UK: Royal Society of Chemistry, 2010.

6. Glen, O.B. Garlic: The Spice Notes of Fragrance first edition, Printed in the United States of America, 2012, Pp 63-65.

7. Saba, F., Mohammad, Z.Q. Sabiha, K. and Rukhshan, K. Effect of feeding garlic (allium sativum) on body weight and serum cholesterol levels in rats. Pakistan Journal of Physiology, 2011, 7(1): 1-2. 
8. Lakshmi.T. Anitha, R. Durgha, K. and Manjusha, V. Coping With Hypertension Using Safer Herbal Medicine - $A$ Therapeutic Review International Journal of Drug Development \& Research, 2011, 3: 3-4.

9. Ried, K. Frank, O.R. and Stocks, N. P. Aged garlic extract lowers blood pressure in patients with treated but uncontrolled hypertension: a randomized controlled trial". Maturitas, 2010, 67 (2): 144 - 150. DOI: $10.1016 /$ j.maturitas.2010.06.001

10. Shuford, J.A., Steckelberge, J.M. and Patel, R. Effect of fresh garlic extract on Candida albicans biofilms. Antimicrobial Agents and Chemotherapy, 2010, 49(1): 473-473.

DOI:
11. Mahmood, Z.A. Ahmed, S.W. and Mahmood, S.B.Z. Hyperlipidemia development and consequences. Journal of Medical Channel, 2009, 15(3): 14-17.

12. Saba, F. Mohammed, Z.Q., Sabiha, K. and Rukhshan, K. Effect of feeding garlic (Allium savitum) on body weight and serum cholesterol levels in Rats, 2011, Pakistan Journal of Physiology.

13. Durak, L.M. Kavutcu, B. Aytac, A. Avci, E. Devrim, H. O. and Oxtürk, S.H. Effect of garlic extract consumption on blood lipid and oxidant/antioxidant parameters in humans with high blood cholesterol. Journal of Nutritional Biochemistry, 2004, 15 (6): 373-377. DOI: 10.1016/j.jnutbio.2004.01.005

$\underline{10.1128 / \mathrm{AAC} .49 .1 .473 .2005}$ 